\title{
Evaluasi Perubahan Penggunaan Lahan Kecamatan di Daerah Aliran Sungai Cisadane Kabupaten Bogor
}

\section{Tessie Krisnaningtyas Endang Trimarmanti ${ }^{1}$}

Direktorat Jenderal Penataan Ruang, Kementerian Pekerjaan Umum

Jakarta, Indonesia

\begin{abstract}
Abstrak: Kabupaten Bogor bagian dari Kawasan Strategis Nasional Jabodetabekpunjur, berperan sebagai kawasan penyangga. Namun demikian, kemudahan aksesibilitas menjadikan Kabupaten Bogor sebagai salah satu pusat pengembangan permukiman perkotaan dan kegiatan perekonomian lainnya. Terdapat 2 kawasan pelestarian alam dan 7 Daerah Aliran Sungai (DAS), yang terluas adalah DAS Cisadane, kaya akan keanekaragaman hayati, digunakan untuk kebutuhan sehari-hari, dan juga DAS yang rentan terhadap perubahan penggunaan lahan terutama wilayah dengan kepadatan penduduknya relatif tinggi. Tujuan penelitian ini adalah untuk mengetahui perubahan penggunaan lahan dan faktor-faktor pengaruh perubahan penggunaan lahan Kecamatan di DAS Cisadane Kabupaten Bogor. Penelitian menggunakan metode kombinasi dengan jenis penelitian berseri/berganda, fase pertama adalah pendekatan keruangan dan analisis kuantitatif, kemudian fase kedua adalah pendekatan kualitatif. Berdasarkan hasil pembahasan dan temuan hasil penelitian, perluasan perkembangan permukiman di wilayah pinggiran perkotaan dan konversi lahanlahan produktif (Rustiadi et.al, 2003) memang benar terjadi di DAS Cisadane, aktivitas perkotaan berdampak terhadap alih fungsi lahan pertanian menjadi lahan perumahan/permukiman. Perubahan penggunaan lahan telah terjadi sebelum ditetapkannya menjadi kawasan pertanian lahan basah. Faktor sosial ekonomi memicu para pengembang mengalihfungsikan lahan pertanian menjadi kawasan perumahan dengan nilai tambahnya, tak terkecuali warga dengan hak kepemilikannya. Faktor lainnya yaitu faktor kelembagaan, kurangnya komitmen pelayanan pemerintah terhadap infrastruktur saluran irigasi dan keberlanjutan aliran irigasi. Penerapan pengendalian pemanfaatan ruang telah dilakukan oleh aparat kecamatan dan aparat kabupaten melalui kegiatan pengawasan dan penertiban sesuai ketentuan RTRW/IMB, namun hal ini belum diimbangi oleh sosialisasi kepada masyarakat, sehingga banyak masyarakat maupun aparat pelaksana belum mengetahui dan memahami peraturan tersebut sehingga kecenderungan terjadinya alih fungsi lahan cukup tinggi.
\end{abstract}

Kata Kunci: daerah aliran sungai, perubahan penggunaan lahan, wilayah peri-urban

\begin{abstract}
Bogor Regency is part of the National Strategic Area Jabodetabekpunjur, serves as the buffer area. However, it is not denied, accessibility making the Bogor Regency as one of the development center urban settlement and other economic activities. There are two Nature Conservation Area and seven Watershed, the greatest area is Cisadane Watershed, rich biodiversity, daily needs, but susceptible of land use change, especially high population area. The purpose study is to find out land use change and its influence factors on sub-district located in Cisadane Watershed, Bogor Regency. This study used mixed methodes research with series/multiply research, the first is spatial approach and quantitative analysis and the second is qualitative approach. Based on the discussion and findings research, the expansion
\end{abstract}

\footnotetext{
${ }^{1}$ Korespondensi Penulis: Direktorat Jenderal Penataan Ruang, Kementerian Pekerjaan Umum, Jakarta Email: tessie_ket@yahoo.com; tessieket@gmail.com
} 


\section{Evaluasi Perubahan Penggunaan Lahan Kecamatan di Daerah Aliran Sungai Cisadane Kabupaten Bogor}

development settlement in the suburban areas and productive lands convertion (Rustiadi et.al, 2003) happens in Cisadane watershed, urban activities have an impact transformation land use, agricultural into housing/settlement land was truly indeed. It had been occured before the provision of wetland agricultural area. Economic-social factors trigger developers the function of agricultural into housing with value added, no exception resident with the right ownership. Another factor is institutional factors, lack of commitment service from government to presence infrastructure and sustainability irrigation flow. The application of space utilization control has been conducted by sub- district and district officials through supervision and control accordance with the provisions of RTRW/IMB regulation, but this has offset by socialization to the public so a lot of society and officials government have yet know and understand the rules, so tendency land use change is quite high.

Keywords: peri-urban areas, watershed, land land-use change

\section{Pendahuluan}

Kabupaten Bogor adalah bagian dari Kawasan Strategis Nasional Jabodetabekpunjur, merupakan kawasan metropolitan nasional besar di Indonesia, bagiannya adalah ibukota negara Indonesia dan kabupaten/kota yang cukup berkembang pesat. Kabupaten Bogor mengalami laju pertumbuhan penduduk $1,07 \%$ dari tahun 2000 hingga 2005, dan meningkat pada periode 5 tahun berikutnya yaitu 5,22\% pada tahun 2010 (BPS Kabupaten Bogor, 2011 dan hasil analisis, 2013). Fenomena perkembangan wilayah lambat laun akan menjadikan penggunaan lahan tidak sesuai kemampuan lahan, daya dukung lahan, dan peruntukannya, sehingga terjadi perubahan penggunaan lahan. Bintarto (1984:35-37) menuliskan bahwa kepadatan penduduk, pertambahan penduduk, perkembangan ekonomi akibat urbanisasi yaitu perluasan penduduk kota ke pinggiran kota, tidak diimbangi ketersediaan ruang yang digunakan untuk pemenuhan kebutuhan perumahan, perkantoran, perindustrian, sehingga menyebabkan perubahan penggunaan lahan bagi daerah-daerah hijau dan terganggunya kualitas lingkungan.

Sebagian besar wilayah Kabupaten Bogor berfungsi sebagai kawasan penyangga, dikarenakan secara geografis letaknya di bagian hulu. Namun demikian, aksesibilitas yang tinggi menjadikan Kabupaten Bogor sebagai salah satu pusat pengembangan permukiman perkotaan dan pus at kegiatan perekonomian, seperti: penghasil produk pertanian, perdagangan dan jasa (wisata alam dan wisata kuliner), kawasan industri (industri kecil maupun industri menengah) dan lain sebagainya. Data BPS Kabupaten Bogor (2011) tentang PDRB tahun 2010-2011 memperlihatkan 3 sektor terbesar penyumbang PDRB adalah sektor industri pengolahan sebesar $60,96 \%$; sektor perdagangan, hotel dan restoran $17,19 \%$; dan sektor pertanian sebesar 4,69\%.

Selain terdapat 2 Taman Nasional, Gunung Halimun Salak dan Gunung Gede Pangrango di bagian selatan, Kabupaten Bogor juga dialiri 7 DAS yang berada dalam satuan wilayah Sungai Ciliwung Cisadane yaitu DAS Cidurian, DAS Ciliwung, DAS Cimanceuri, DAS Cisadane, DAS Citarum, DAS Ciujung, dan Kali Bekasi. DAS dengan luasan terbesar adalah DAS Cisadane, yaitu 113.511 ha (Herawati, 2010), dengan panjang sungai $+76 \mathrm{~km}$, dan anak sungai 58 buah dengan total panjang sungai 639,3 km (Materi Teknis RTRW Kabupaten Bogor, 2005-2025). Menurut Alberto et.al (2010), DAS Cisadane merupakan salah satu DAS yang penting di provinsi Jawa Barat, kaya sumber daya alam digunakan untuk kebutuhan sehari-hari, dan juga DAS yang rentan terhadap perubahan penggunaan lahan, terutama di daerah Bogor dan Tangerang dengan kepadatan penduduknya relatif tinggi.

Penggunaan lahan yang sesuai dengan peruntukannya dapat menjaga kelestarian lingkungan dan mencegah terjadinya penurunan kualitas lingkungan, sedangkan 
penggunaan lahan yang tidak sesuai dapat menjadi malapetaka bagi lingkungan dan kehidupan manusia itu sendiri. Dengan adanya pertumbuhan penduduk dan aktivitas pembangunan serta perekonomian yang tinggi, memicu terjadinya perubahan penggunaan lahan yang disebabkan atas peningkatan kebutuhan lahan untuk kegiatan industri, perdagangan jasa, serta hunian, khususnya di DAS Cisadane bagian hulu yang merupakan kawasan konservasi air dan tanah.

Penelitian ini bertujuan untuk mengetahui perubahan penggunaan lahan dan faktorfaktor pengaruh perubahan penggunaan lahan kecamatan di wilayah DAS Cisadane Kabupaten Bogor, dengan sasaran penelitian adalah:

1. Mengetahui perencanaan tata ruang tahun 2005-2025 dan pemanfaatan ruang tahun 2010 di wilayah DAS Cisadane Kabupaten Bogor, dan apakah pemanfaatan ruang tahun 2010 telah sesuai rencana pola ruang RTRW Kabupaten Bogor tahun 20052025.

2. Mengetahui faktor-faktor pengaruh perubahan penggunaan lahan tahun 2010 beberapa kecamatan di wilayah DAS Cisadane Kabupaten Bogor.

3. Mengetahui pengendalian pemanfataan ruang beberapa kecamatan yang mengalami perubahan penggunaan lahan di wilayah DAS Cisadane Kabupaten Bogor.

\section{Gambaran Umum Wilayah}

DAS Cisadane terletak pada 6o72' sampai 6o76' LS dan 106o58' sampai 106o51' BT, terbagi menjadi 4 sub DAS, yaitu 2 di bagian hulu (Cianten dan Cisadane Hulu), 1 sub DAS di bagian tengah dan 1 sub DAS di bagian hilir. Berdasarkan batas administrasi, DAS Cisadane mencakup 518 desa yang tersebar di 44 kecamatan di 5 kabupaten/kota yaitu Kabupaten Bogor, Kota Bogor Kabupaten Tangerang, Kota Tangerang, dan Kota Tangerang Selatan (BPDAS Citarum dan Ciliwung, 2012). Wilayah studi penelitian adalah kecamatan-kecamatan yang secara administrasi berada di wilayah DAS Cisadane Kabupaten Bogor, terdiri dari 23 kecamatan; 7 berada di sub DAS Cisadane Tengah yaitu Cigudeg, Rumpin, Ranca Bungur, Kemang, Ciseeng, Parung, dan Gunung Sindur; 10 berada di sub DAS Cisadane Hulu yaitu Ciampea, Dramaga, Ciomas, Tenjolaya, Tamansari, Cijeruk, Cigombong, Caringin, Ciawi, dan Megamendung; dan 6 berada di sub DAS Cianten yaitu Sukajaya, Nanggung, Leuwisadeng, Leuwiliang, Cibungbulang, dan Pamijahan. DAS Cisadane mempunyai ketinggian yang sangat beragam dengan dominasi daerah yang berbukit dan bergelombang. Pada sub DAS Cisadane Hulu 45,6\% wilayahnya berada pada ketinggian 200-500 m, sedangkan sub DAS Cianten 40,5\% wilayahnya berada pada ketinggian 500-1000 m. Wilayah tengah dan hilir DAS Cisadane didominasi oleh daerah yang relatif landai dengan ketinggian 0-200 m. Kawasan hijau tersebar lebih banyak di bagian hulu yaitu $\pm 33 \%$. Penutupan lahan di bagian hulu di dominasi oleh lahan pertanian semusim, ladang, sawah dan tegalan (BPDAS Citarum dan Ciliwung, 2012).

Jumlah penduduk di DAS Cisadane berdasarkan sensus penduduk tahun 2010 yaitu 3,49 juta jiwa dengan tingkat kepadatan penduduk 23 juta jiwa/Ha, dengan sebaran penduduk paling banyak di sub DAS Cisadane Tengah 39,8\% dan sub DAS Cisadane Hulu $30 \%$. Beberapa kecamatan mengalami $>30 \%$ kenaikan jumlah penduduk tahun 2005 hingga 2010 yaitu Ciomas, Dramaga, Caringin, Parung, dan Rumpin. Kecamatan dengan kepadatan penduduk di atas 2.000 jiwa $/ \mathrm{km} 2$ adalah Ciomas, Tamansari, Cibungbulang, Dramaga, Ciawi, Ciampea, Cijeruk, Ciseeng, Megamendung, Leuwisadeng, Ranca Bungur, Tenjolaya dan Cigombong (BPS Kabupaten Bogor, 2006 dan 2011). Salah satu sektor yang menjadi penyumbang perekonomian Kabupaten Bogor adalah sektor pertanian, penting karena luasan lahan pertanian dan karakter perdesaan yang menitikberatkan kegiatan di bidang pertanian terutama komoditas padi. Tingkat produktivitas yang tinggi dapat 
dijadikan benteng ketahanan pangan di Kabupaten Bogor, maupun wilayah sekitarnya. Selain lahan yang subur, kemajuan ekonomi di bidang pertanian di dukung oleh adanya saluran irigasi yang berada di dalam pengawasan pemerintah.

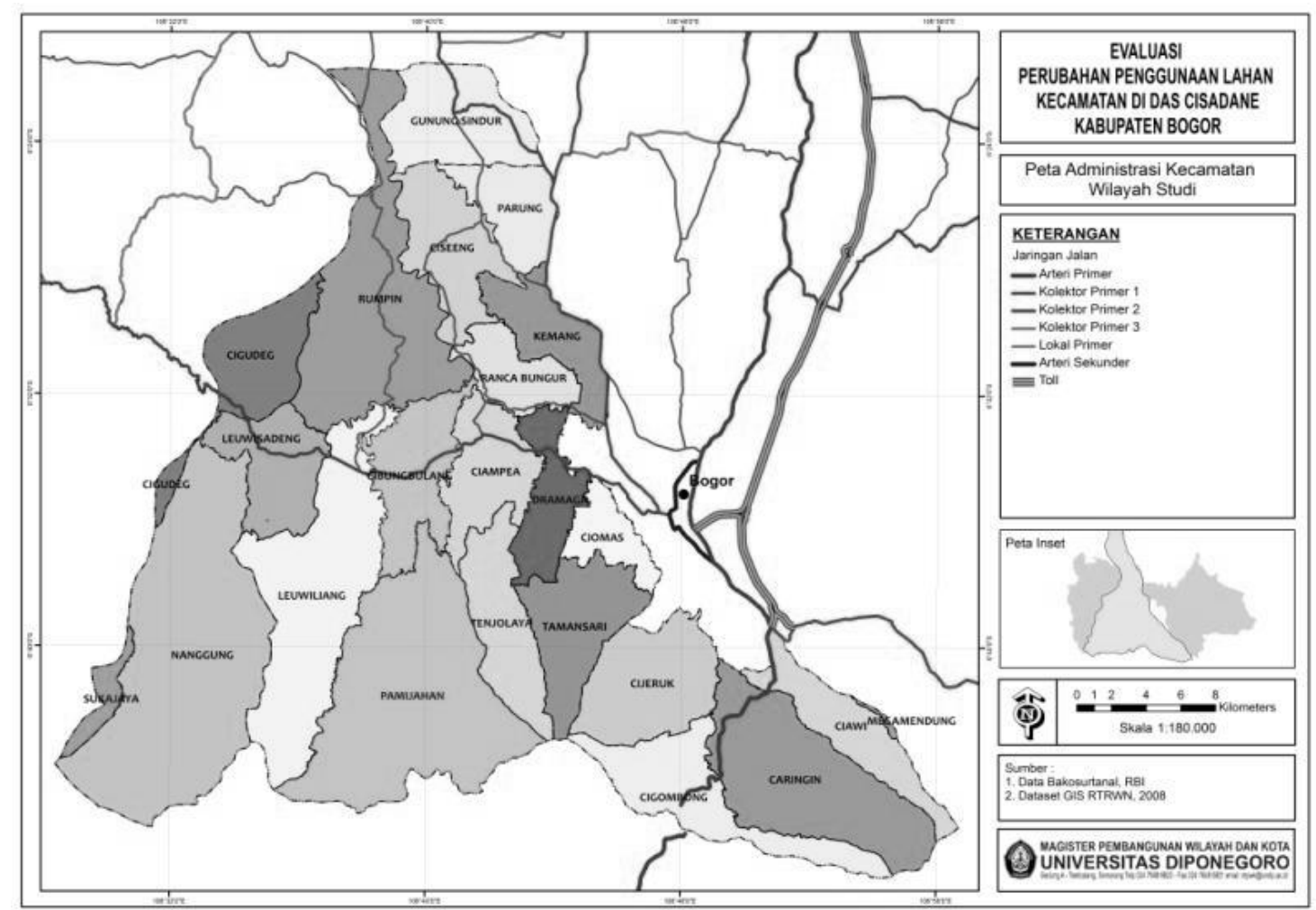

Gambar 1. Peta Administrasi Wilayah Studi

\section{Metodologi Penelitian}

Penelitian ini menggunakan mixed methods research (metode penelitian kombinasi) secara series/multiple study (penelitian berseri/berganda), Creswell dan Clark (2007) menjelaskan bahwa penelitian ini berfokus pada pekerjaan mengumpulkan, menganalisa data, dan memadukan antara data kuantitatif dan data kualitatif. Penelitian ini terdiri dari fase pertama adalah pendekatan keruangan dengan analisis spasial dan analsisis kuantitatif, dan fase kedua adalah pendekatan kualitatif dan analisis kualitatif. Pendekatan keruangan merupakan metoda analisis eksistensi ruang sebagai wadah untuk mengakomodasikan kegiatan manusia, menggunakan spatial process analysis yaitu perubahan ruang didasarkan atas pattern (pola). Perubahan elemen-elemen ruang (pola ruang) ini, dikemukakan secara kualitatif maupun kuantitatif (Yunus, 2008). Dari hasil analisis spasial, dijelaskan secara deskritif guna menjawab pertanyaan what, when dan where yaitu apa, dimana, dan kapan, berkaitan dengan perencanaan ruang (RTRW Kabupaten Bogor tahun 2005-2025), pemanfaatan ruang tahun 2010, dan perubahan penggunaan lahan atas ketidaksesuaian pemanfaatan ruang dengan perencanaan ruang tersebut. Kemudian secara kualitatif guna menjawab why, who, dan how, didasarkan hasil wawancara dengan beberapa narasumber (aparat kecamatan/desa dan warga) di 8 sampel penelitian, diketahui faktor-faktor pengaruh perubahan penggunaan lahan. Menurut Strauss dan Corbin (1990:18-20) penelitian kualitatif yang temuannya tidak diperoleh melalui prosedur 
statistik, namun diperoleh dari data - data yang dikumpulkan secara wawancara, observasi, dan sebagainya. Prosedur analisis dan interpretasi dilakukan dengan penulisan memo, pembuatan diagram dan penandaan/coding.

\section{Kajian Literatur}

Menurut Undang-undang No. 26/2007, kawasan metropolitan merupakan kawasan perkotaan yang terdiri atas sebuah kawasan perkotaan yang berdiri sendiri atau kawasan perkotaan inti dengan kawasan perkotaan di sekitarnya yang memiliki keterkaitan fungsional dihubungkan dengan sistem jaringan prasarana wilayah. Djakapermana (2008) menyatakan bahwa Kawasan Jabodetabekpunjur mempunyai 2 fungsi yang dikotomikan, fungsi ekonomi didukung oleh infrastruktur ekonomi dan sosial yang sudah maju dan terpusat di Jakarta, Bogor, Tangerang dan Bekasi, dan fungsi lingkungan yaitu kawasan dengan bentangan hijau alami berfungsi sebagai konservasi air dan tanah, khususnya Kabupaten Bogor. Rustiadi et.al (2003), proses suburbanisasi ditunjukkan dengan meluasnya perkembangan kawasan permukiman di wilayah pinggiran kota dan proses konversi lahan yang merupakan lahan-lahan produktif. Desrainy (2010:2) menuliskan bahwa pertumbuhan penduduk di Jabodetabek cenderung didorong oleh kekuatan pasar harga lahan dan pemanfaatan lahan, tingginya harga lahan di kawasan inti kota mengakibatkan pergeseran permukiman penduduk ke arah kawasan pinggiran. DAS adalah suatu wilayah yang dibatasi oleh batas alam, seperti punggung bukit-bukit atau gunung, maupun batas buatan seperti jalan atau tanggul, dimana air hujan yang turun memberi kontribusi aliran ke titik kontrol (Suripin, 2003). Puspaningsih (1999) menambahkan penjelasan mengenai daerah hulu DAS berfungsi lindung, fungsi hidrologis dan merupakan daerah resapan air untuk konsumsi air di daerah hilir, serta berpotensi sebagai lahan pertanian bagi petani di daerah hulu itu sendiri.

Dalam pemenuhan kebutuhannya, manusia melakukan aktivitas di dalam atau antar lokasi, oleh karena itu ada hubungan antara manusia dan lokasi disebut penggunaan lahan. Tutupan lahan mengacu pada "benda" yang terletak di permukaan planet, sedangkan penggunaan lahan mengacu pada "benda" yang mewakili aktivitas manusia yang menghasilkan produksi barang dan jasa bagi masyarakat. (Mendoza et.al, 2011). Perubahan penggunaan lahan, yaitu: 1) Perubahan wilayah: peningkatan/penurunan pengggunaan lahan di suatu daerah dari waktu ke waktu, disajikan dalam bentuk statistik, grafis, atau spasial; 2) Transformasi: pola transisi satu penggunaan lahan ke penggunaan lahan yang lain antara periode waktu ke waktu, disajikan dalam matriks perubahan; 3) Dinamika, tingkat perubahan dan periodisitas dalam batas tertentu; dan 4) Prediksi, pemodelan spasial atau temporal dari perubahan penggunaan lahan, dilakukan untuk prediksi masa lalu, sekarang, dan masa (Bryon dan Lesslie, 2008). Menurut Koomen and Stillwell (2007), perubahan penggunaan lahan merupakan proses transformasi atau alokasi. Transformasi adalah perubahan jenis penggunaan lahan yang satu menjadi penggunaan lahan lainnya, didasarkan kemampuan lahan/kondisi lokasi sekitarnya. Sedangkan alokasi adalah probabilitas transformasi atau status lokasi sekitarnya. Menurut Mendoza et.al (2011) perubahan tutupan lahan dan penggunaan lahan secara langsung berkaitan dengan ketahanan pangan, jaminan kesehatan, manusia, urbanisasi, hilangnya keanekaragaman hayati, migrasi, pelestarian lingkungan, kualitas air dan tanah, dan air limpasan dan tingkat sedimentasi, dan proses lainnya.

Berdasarkan teori dan kajian empirik, aktivitas manusia pasti membutuhkan lahan, berinteraksi dan berwujud penggunaan lahan. Dengan peningkatan jumlah pertumbuhan penduduk dan pertumbuhan perekonomian wilayah, serta terbatasnya lahan menimbulkan perubahan penggunaan lahan. Perubahan penggunaan lahan di DAS dapat menyebabkan 
degradasi lingkungan DAS hulu, tengah maupun hilir. DAS merupakan suatu ekosistem yang terdiri dari unsur biotik dan abiotik yang terletak di bentangan alam yang bukan merupakan suatu wilayah administrasi tetapi mempunyai nilai ekologis penting karena fungsinya sebagai kawasan resapan air, kawasan perlindungan setempat, kawasan konservasi tanah dan air, dan fungsi hidrologisnya. Berdasarkan teori dan kajian empirik yang telah dilakukan untuk melihat perubahan penggunaan lahan di berbagai wilayah DAS, faktor-faktor yang mempengaruhi perubahan penggunaan lahan yaitu faktor alami/karakteristik fisik DAS seperti curah hujan, jenis tanah, kemiringan lereng dan vegetasi; faktor aktivitas manusiai atau faktor sosial-ekonomi seperti: jumlah penduduk, kepadatan penduduk, mata pencaharian, pola pikir dan pola perilaku penduduk, dan yang terakhir adalah faktor kelembagaan.

Dalam wilayah daerah aliran sungai Cisadane dan administrasi Kabupaten Bogor, berlaku kebijakan pemerintah terkait penataan ruang dan pengelolaan DAS terpadu. Kedua kebijakan ini harus menjadi arahan proses pembangunan dan pengembangan di wilayah tersebut. Secara normatif, Perda Nomor 19 Tahun 2008 tentang RTRW Kabupaten Bogor Tahun 2005-2025 dijadikan acuan untuk mengarahkan pembangunan di Kabupaten Bogor dengan memanfaatkan ruang wilayah secara berdaya guna, berhasil guna, serasi, selaras, seimbang, dan berkelanjutan dalam rangka meningkatkan kesejahteraan masyarakat dan pertahanan keamanan, serta mewujudkan dinamisasi dan keterpaduan pembangunan antar sektor, daerah, dan masyarakat.

Dalam konteks pelaksanaan, penataan ruang adalah suatu sistem proses perencanaan tata ruang, pemanfaatan ruang, dan pengendalian pemanfaatan ruang. Perencanaan tata ruang adalah suatu proses untuk menentukan struktur ruang dan pola ruang yang meliputi penyusunan dan penetapan rencana tata ruang. Pemanfaatan ruang adalah upaya untuk mewujudkan struktur ruang dan pola ruang sesuai dengan rencana tata ruang melalui penyusunan dan pelaksanaan program beserta pembiayaannya. Pengendalian pemanfaatan ruang adalah upaya mewujudkan tertib tata ruang yang sesuai dengan rencana tata ruang yang telah ditetapkan.

Pengelolaan daerah sungai merupakan salah satu kebijakan pemerintah yang sangat kompleks, karena didalamnya terdiri dari berbagai arahan kebijakan, berbagai pemangku kepentingan, berbagai kepentingan sektoral, berbagai keanekaragaman hayati, dan sebagainya. DAS yang sifatnya lintas Kementerian, lintas wilayah, lintas kepentingan ini menjadikannya sebagai subyek dengan berbagai arahan kebijakan, sehingga dibutuhkan keterpaduan. Selain itu, DAS memang mempunyai nilai penting bagi keberlanjutan suatu wilayah, karena erat kaitannya dengan air, tanah, dan sumber daya alam lainnya, ditambah lagi dengan permasalahan yang sering terjadi seperti: erosi/tanah longsor, banjir, kekeringan, pencemaran yang menjadi penting karena berkaitan erat dengan makhluk hidup didalamnya.

\section{Analisis Evaluasi Perubahan Penggunaan Lahan Di Wilayah Daerah Aliran Sungai Cidasane Kabupaten Bogor}

Fase pertama penelitian didasarkan atas analisis spasial dan analisis kuantitatif, dihasilkan 4 peta yaitu peta rencana pola ruang wilayah studi tahun 2005-2025 dan peta penggunaan lahan wilayah studi tahun 2010 (Gambar 1), serta peta kesesuaian wilayah studi dan peta perubahan penggunaan lahan (Gambar 3).

\section{Perencanaan Ruang: Rencana Pola Ruang Wilayah Studi Tahun 2005-2025}

Sesuai dengan Perda No.19 Tahun 2008 tentang RTRW Kabupaten Bogor Tahun 20052025, arahan pola ruang wilayah studi seluas 108.284,12 Ha dengan distribusi kawasan 
lindung seluas 27.538,01 Ha (25,43\%) merupakan kawasan hutan konservasi, sedangkan kawasan budidaya seluas $80.746,11 \mathrm{Ha}(74,57 \%)$, di dominasi oleh lahan pertanian basah $22,78 \%$, tanaman tahunan $10,36 \%$, permukiman perkotaan hunian padat $10,92 \%$ dan permukiman perkotaan hunian sedang 9,82\%. Beberapa kecamatan terletak di kaki gunung atau merupakan bagian dari kawasan pelestarian alam TN Gunung Gede Pangarango, seperti: Megamendung, Cigombong dan Caringin, sedangkan TN Gunung Halimun dan Gunung Salak, seperti: Kecamatan Sukajaya, Nanggung, Leuwiliang, Pamijahan, Cigombong, Tamansari, dan Tenjolaya (RTRW Kabupaten Bogor, 2008).
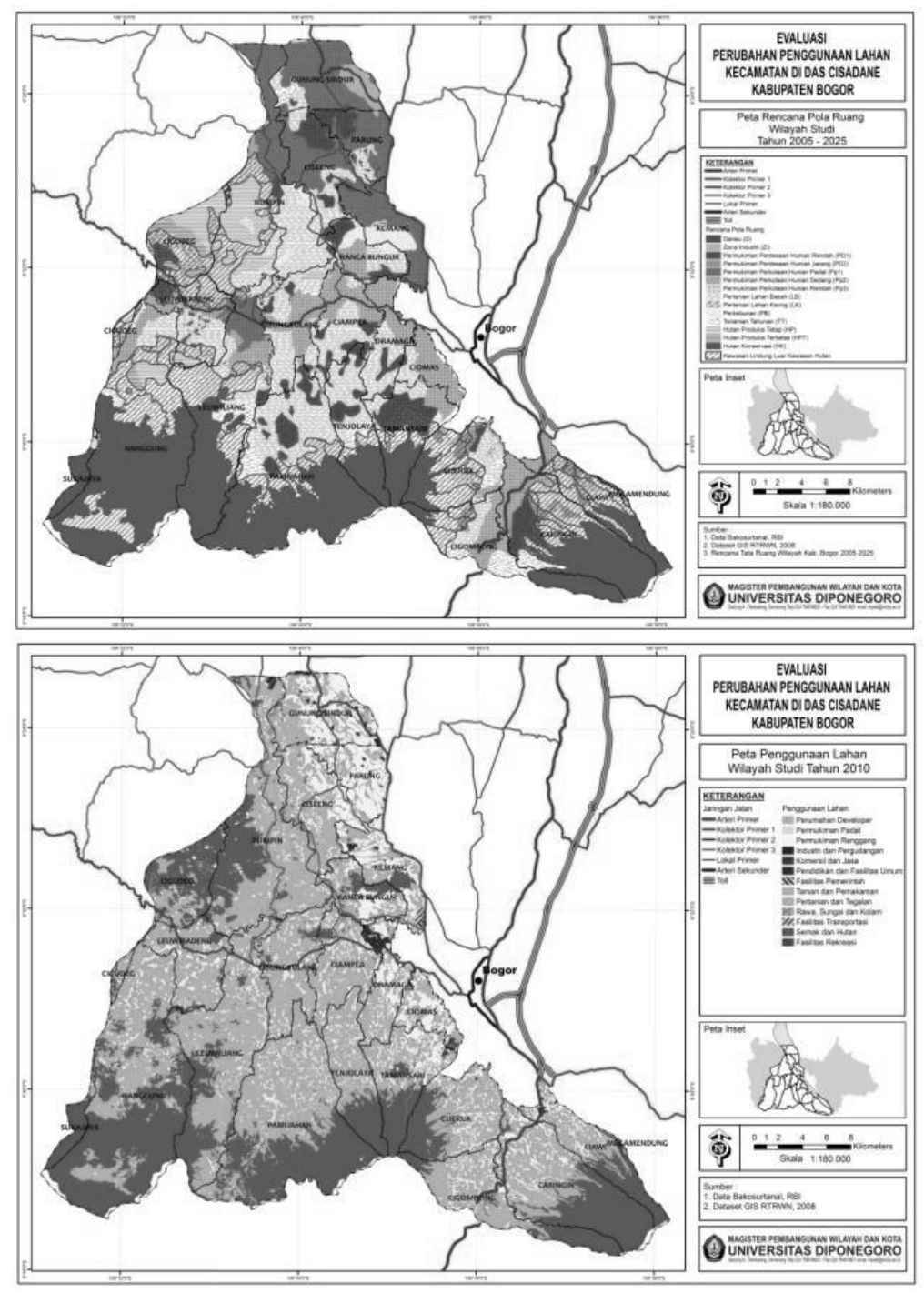

Gambar 2. Peta Pola Ruang Wilayah Studi Tahun 2005-2025 dan Peta Penggunaan Lahan Tahun 2010

\section{Pemanfaatan Ruang: Penggunaan Lahan Wilayah Studi Tahun 2010}

Prosentase terbesar luasan penggunaan lahan adalah pertanian dan tegalan 53,6\%; semak dan hutan 28,8\%; permukiman renggang 14,82\%; rawa, sungai dan kolam 1,05\%; perumahan developer $0,73 \%$; dan sisanya $2,79 \%$ adalah permukiman padat; industri dan pergudangan; komersil dan jasa; dan fasilitas lainnya. Sesuai teori penggunaan lahan, kaidah penataan ruang dan pengelolaan daerah aliran sungai, pemanfaatan ruang 
merupakan kombinasi 3 elemen yaitu ruang sebagai wadah sumberdaya alam atau bentang alam tempat manusia beraktivitas, manusia sebagai pengguna sumber daya alam, dan aktivitas sebagai bentuk kegiatan menggunakan sumber daya alam tersebut. Pemanfaatan ruang eksisting tahun 2010 wilayah studi menunjukan bahwa dominasi penggunaan lahan untuk kawasan pertanian dan hutan berada di urutan kedua terbesar.

Penggunaan lahan masih mempertahankan bentuk-bentuk natural dari bentang alam sebagai penghasil dari sumber daya alam, sehingga kelestarian dan keberlanjutan lingkungan masih terjaga. Namun demikian, apakah pemanfaatan ruang sudah sesuai dengan ketetapan dalam perencanan ruang, ini akan di bahas dalam sub bagian di bawah ini.

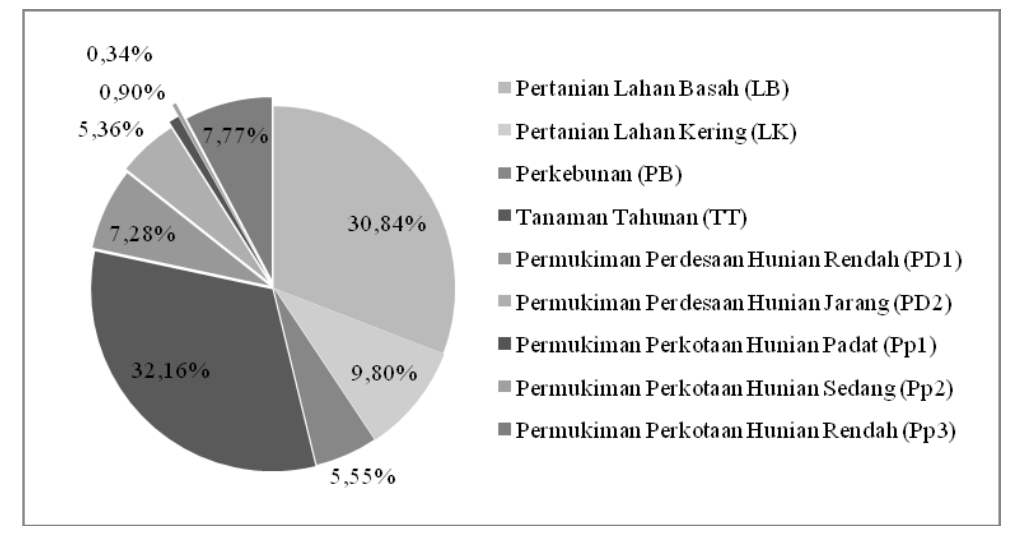

Gambar 3. Prosentase Kawasan Lindung di Luar Kawasan Hutan (RTRW) Wilayah Studi

\section{Kesesuaian dan Perubahan Pengggunaan Lahan Wilayah Studi Tahun 2010 vs Rencana Pola Ruang Wilayah Studi Tahun 2005-2025}

Dari hasil analisis tumpangsusun antara peta pola ruang dan peta penggunaan lahan, terbagi menjadi 3 yaitu sesuai $63,39 \%$, kurang sesuai $26,38 \%$ dan tidak sesuai $10,23 \%$. Bahwa $>50 \%$ pemanfaatan ruang sudah sesuai dengan rencana pola ruang yang, hal ini menunjukkan bahwa penggunaan lahan pada tahun 2010 sudah sesuai dengan karateristik dan potensi wilayah yang tertuang secara normatif di dalam RTRW Kabupaten Bogor 2005-2025. Bahwa penggunaan lahan telah mempertimbangkan alokasi peruntukkan kawasan sebagai fungsi lindung maupun budidaya, sehingga pemanfaatan ruangnya sesuai peruntukkannya. Sebesar $10,23 \%$ pemanfaatan ruang tidak sesuai dengan ketetapan rencana pola ruang RTRW Kabupaten Bogor. Meskipun prosentasenya sedikit, perubahan penggunaan lahan ini mengindikasikan bahwa perencanaan ruang belum diimplementasikan secara penuh oleh para pelaku pembangunan ke dalam sebuah pemanfaatan ruang. Dan yang lebih penting, kaidah penataan ruang dan pengelolaan daerah aliran sungai, kurangnya pengendalian pemanfaatan ruang dalam upaya mempertahankan fungsi lingkungan Kabupaten Bogor yaitu kawasan yang berfungsi sebagai kawasan resapan air dan atau kawasan penyangga bagi Kawasan Strategis Nasional Jabodetabekpunjur. Pemanfaatan ruang yang tidak terkendali ini, menyebabkan dampak negatif terhadap ekosistem wilayah Kabupaten Bogor yang merupakan bagian hulu daerah aliran sungai Cisadane dan kawasan perlindungan bagi bagian hilirnya, hal ini disebabkan oleh faktor utama yaitu manusia sebagai pelaku ataupun pengintervensi terjadinya perubahan penggunan lahan. 

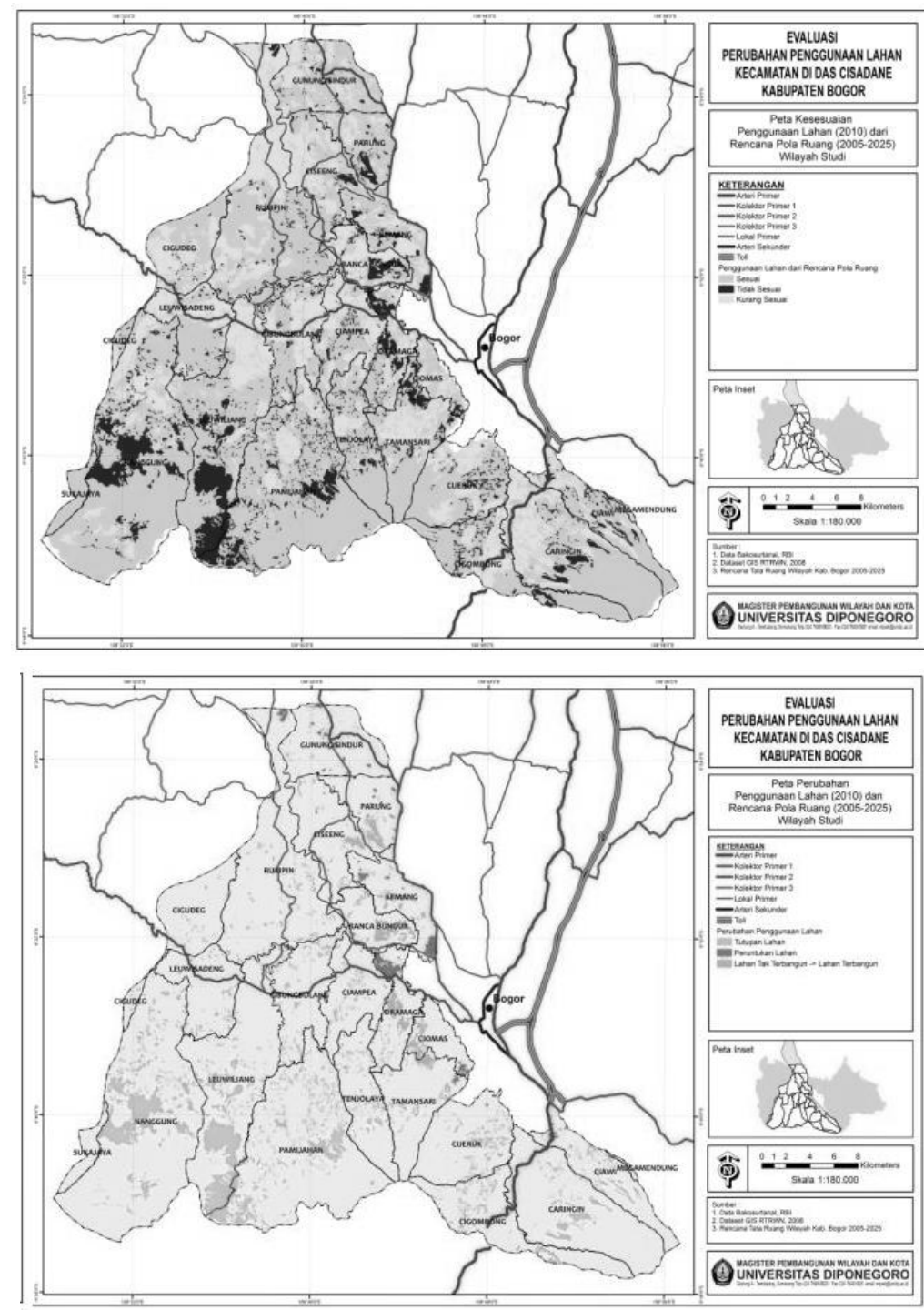

\section{Gambar 4. Peta Kesesuaian Rencana Pola Ruang dan Peta Perubahan Penggunaan Lahan}

Dari 3 jenis perubahan penggunaan lahan yaitu perubahan tutupan lahan 47,65\%; perubahan lahan tak terbangun menjadi lahan terbangun 44,33\%; dan perubahan peruntukan lahan sebesar $8,02 \%$. Terdapat 2 jenis perubahan penggunaan lahan yang mendominasi yaitu pe rubahan tutupan lahan dan perubahan lahan tak terbangun menjadi lahan terbangun. Perubahan tutupan lahan di 3 kecamatan yaitu Leuwiliang, Nanggung dan Pamijahan yang berada di kawasan pelestarian alam TN Gunung Halimun Salak. Perubahan tutupan lahan ini menunjukkan bahwa terdapat lahan-lahan yang telah ditetapkan sebagai kawasan konservasi hutan berubah penggunaannya menjadi lahan pertanian. Kegiatan pertanian telah merambah kawasan hutan yang berfungsi sebagai kawasan resapan air, namun demikian penggunaan lahan pertanian yang masih mempertahankan bentang alam berupa vegetasi dan juga bentuk kegiatan pertanian yang memperhatikan kaidah konservasi. Sedangkan perubahan lahan tak terbangun menjadi lahan terbangun yang terjadi di seluruh kecamatan wilayah studi menunjukkan bahwa adanya bangunan-bangunan di wilayah Kabupaten Bogor yang sebagian besar merupakan kawasan resapan air. Hal ini berakibat mengurangi fungsi tanah sebagai material penyerap 


\section{Evaluasi Perubahan Penggunaan Lahan Kecamatan di Daerah Aliran Sungai Cisadane Kabupaten Bogor}

dan penyimpan air, dan jikalau berlebihan dapat menyebabkan banjir. Bangunan-bangunan berupa permukiman/perumahan, bangunan komersil dan jasa, maupun bangunan fasilitas umum lainnya berdiri di atas lahan dengan karakteristik lahan yang rawan terhadap kejadian longor maupun rawan terhadap gerakan tanah.

\section{Faktor-Faktor Pengaruh Perubahan Penggunaan Lahan}

Wilayah studi yang merupakan bagian dari wilayah DAS Cisadane adalah wilayah yang mempunyai peranan penting bagi kelestarian sumberdaya alam, keseimbangan ekologis dan kondisi hidrologis, penyedia air untuk irigasi lahan-lahan pertanian, bahan baku produksi bagi industri kecil/menengah ataupun besar, serta sebagai pengendali banjir pada musim hujan. Menurut BPDAS Citarum dan Ciliwung (2012), pemanfaatan DAS Cisadane telah dilakukan sejak zaman Kerajaan Tarumanegara dan Kerajaan Pajajaran dibuktikan dengan keberadaan prasasti di bagian tengah-hulu DAS Cisadane seperti: Prasasti Ciaruteun, Jambu, Cianten, Batu Tulis. Saat ini, pemanfaatan air tidak hanya terbatas pada sektor pertanian saja melainkan juga untuk memenuhi kebutuhan industri dan domestik. Demikian informasi Bapak Dedi Supriadi (Sekcam Pamijahan), aliran air sungai bagian hulu ini dimanfaatkan untuk kebutuhan pertanian mengirigasi sawah, peternakan sebagai makan ternak sapi, dan penggerak turbin geotherm untuk listrik (Hasil Wawancara, 2013). Hal ini tidak lepas dari kondisi alamiah wilayah studi yang potensi dan posisinya merupakan kawasan hutan konservasi 26.853 Ha yaitu TN Gunung Halimun Salak, TN Gunung Gede Pangrango dan Hutan Produksi Tetap 3.101 Ha serta Hutan Produksi Terbatas $757 \mathrm{Ha}$ (RTRW Kabupaten Bogor, 2008 dan BPDAS Citarum Ciliwung, 2012).

Namun tidak dipungkiri, dibalik keunggulannya tersebut menimbulkan masalahmasalah yang menyebabkan rusaknya kelestarian lingkungan, terganggunya keseimbangan ekologis, tercemarnya air, dan yang paling membahayakan adalah kejadian tanah longsor dan banjir yang terjadi di daerah hulu sampai hilir di sekitar Kabupaten Bogor, Kota Bogor, Kabupaten Tangerang dan Kota Tangerang. Sesuai dengan hasil penelitian dari Zamrin (2007) bahwa indeks mutu kualitas air sungai Cisadane yang pada tahun 1999 adalah kategori baik, namun tahun 2000-2003 adalah kategori sedang, salah satunya disebabkan penurunan luas penggunaan lahan seperti sawah irigasi, semak belukar air, sawah tadah hujan, perkebunan, dan hutan/vegetasi campuran.

Pada fase kedua penelitian ini, faktor-faktor pengaruh perubahan penggunaan lahan difokuskan pada lahan tak terbangun menjadi lahan terbangun di penggunaan lahan tahun 2010 di wilayah studi. Hal ini didasarkan bahwa wilayah DAS daerah hulu tengah harus dijaga kelestarian vegetasinya, supaya tetap terjaga fungsinya sebagai kawasan resapan. Bahwa telah terjadi perkerasan lahan diakibatkan perubahan lahan pertanian basah menjadi lahan perumahan/permukiman. Hal ini kemudian, berakibat terhadap percepatan limpasan air hujan yang turun, sehingga menyebabkan kejadian banjir di daerah hulu tengah sendiri maupun daerah hilir dari DAS Cisadane. Hasil penelitian dari Emilda (2010) menunjukkan bahwa aliran permukaan pada penggunaan lahan tahun 2007 lebih besar dibandingkan volume aliran permukaan tahun 1997 dan 2002. Hal ini disebabkan oleh luasan hutan yang berada di hulu DAS Cisadane mengalami penurunan dan beralih fungsi menjadi kegiatan pertanian/ladang berpindah. Selain itu peningkatan alih fungsi hutan/pertanian menjadi permukiman mengakibatkan berkurangnya daerah resapan air, sehingga hujan yang jatuh tidak dapat diserap tetapi langsung menjadi aliran permukaan.

Berdasarkan hasil wawancara narasumber hasil observasi lapangan di 8 kecamatan yaitu Pamijahan, Cibungbulang, Ciampea, Dramaga, Ciomas, Ranca Bungur, Ciseeng dan Parung; perubahan lahan pertanian basah menjadi lahan perumahan/permukiman disebabkan 2 faktor yaitu sosial-ekonomi (internal) dan faktor kelembagaan (eksternal). Faktor sosial-ekonomi (internal) yaitu faktor yang berasal dari masyarakat/pengembang 
perumahan sebagai pelaku pengguna lahan maupun pengalihfungsi lahan pertanian menjadi rumah tinggal /perumahan, sedangkan faktor kelembagaan (eksternal) yaitu faktor yang bukan berasal dari masyarakat/pengembang perumahan, melainkan berasal dari pemerintah sebagai pembuat kebijakan/peraturan, dan penyedia sarana prasarana/infrastruktur saluran irigasi yang berfungsi sebagai pendukung utama keberlanjutan dan produktivitas lahan pertanian basah. Faktor sosial- ekonomi (internal) antara lain: kebutuhan rumah tinggal dan kepemilikan lahan, lokasi strategis dan kemudahan aksesibilitas, dan ketidaktahuan /ketidakpahaman terhadap Perda RTRW/IMB, sedangkan faktor kelembagaan (eksternal) antara lain: kurang intensifnya sosialisasi mengenai Perda RTRW/IMB dan kurangnya dukungan pemerintah terhadap infrastruktur saluran irigasi dan aliran air irigasi yang berfungsi mengaliri lahan pertanian.

\section{Kebutuhan Rumah Tinggal dan Kepemilikan Lahan}

Kebutuhan akan rumah tinggal menjadi faktor utama yang mempengaruhi perubahan penggunaan lahan pertanian, kebutuhan rumah tinggal erat kaitannya dengan kepemilikan lahan. Hampir sebagian besar lahan-lahan pertanian yang berada di kecamatan sampel penelitian adalah milik perseorangan, sehingga dengan mudahnya mereka membangun rumah tinggal di atas lahan yang memang hak miliknya.

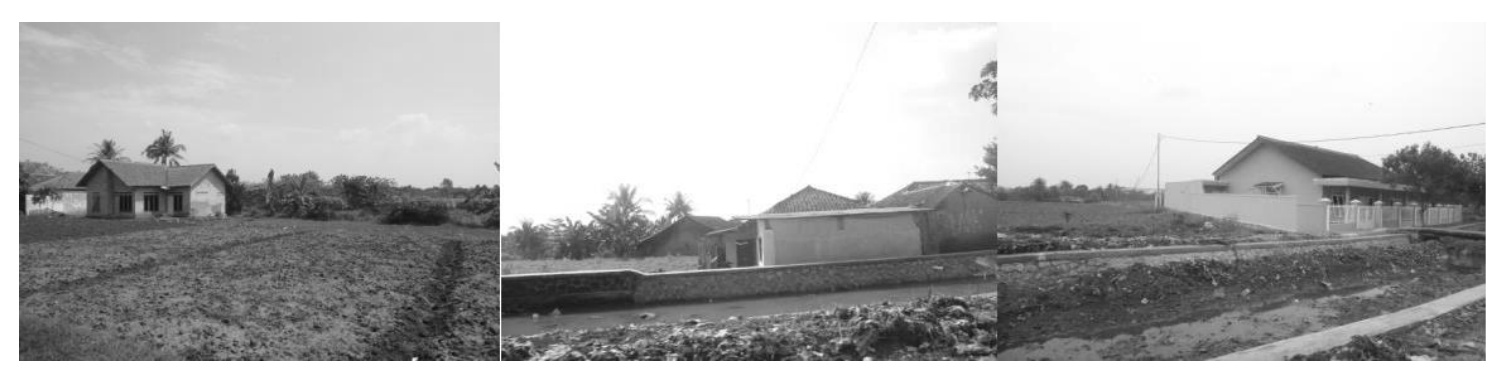

Gambar 5. Bangunan Rumah Tinggal di Atas Lahan Sawah, Kecamatan Ranca Bungur

Secara teori maupun empirik telah banyak dibuktikan bahwa peningkatan jumlah penduduk dan kepadatan jumlah penduduk sebanding lurus dengan peningkatan kebutuhan lahan untuk kebutuhan tempat tinggal/permukiman penduduk. Fenomena perubahan penggunaan lahan pertanian menjadi permukiman juga dibuktikan dengan datadata sekunder seperti data kependudukan. Salah satunya Kecamatan Ciomas dengan kepadatan 8.064 jiwa/km 2 yang merupakan data kepadatan tertinggi di DAS Cisadane Kabupaten Bogor, dengan angka jumlah penduduk datang 279 jiwa, pindah 212 jiwa dan 117 jiwa yang lahir. Tingginya data kependudukan ini menunjukan bahwa semakin banyak lahan yang dibutuhkan untuk tempat tinggal, ditambah lagi dengan angka kelahiran yang tinggi sebagai gambaran peningkatan jumlah rumah tangga. Angka kelahiran sebanding dengan angka pernikahan, dengan menikah sehingga semakin banyak luas lahan pertanian yang berubah menjadi rumah tingal. Isa (2008) menjelaskan bahwa implementasi penataan ruang merupakan penerapan kepentingan publik terhadap tanah yang telah dilekati hak, sehingga diperlukan penyelenggaraan pengaturan penguasaan, pemilikan, penggunaan dan pemanfaatan tanah, sehingga tata ruang akan lebih efektif apabila ditempuh dengan memberikan atau tidak memberikan hak atas tanah. Dalam penelitiannya, Budiman (2009) mengungkapkan fenomena konversi lahan sawah dilakukan oleh petani pemilik lahan menjadi perumahan adalah kebutuhan lahan untuk bangunan rumah meningkat seiring dengan penambahan jumlah anggota keluarga. 


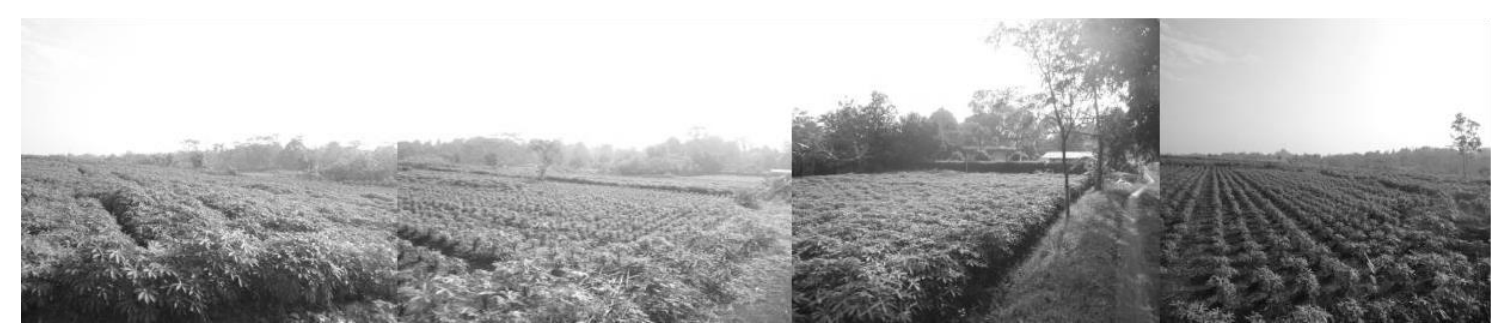

Gambar 6. Hamparan Lahan Pertanian Milik Perusahaan Swasta Di Desa Iwul, Kecamatan Parung

Namun demikian, dibalik fenomena perubahan lahan pertanian basah/kering menjadi permukiman penduduk yang erat kaitannya dengan kepemilikan lahan perseorangan, ternyata diatas lahan pertanian yang cukup luas di Kecamatan Parung dan Kecamatan Ciomas merupakan lahan pertanian dengan kepemilikan atau penguasaan sebuah perusahaan swasta pengembang perumahan. Lahan-lahan pertanian ini digarap oleh penduduk sekitar yang bekerja sebagai buruh tani dan menerima upah, petani memanfaatkan lahan pertanian dengan sistem bagi hasil dengan pemilik lahan, dan petani yang menyewa lahan dengan sistem kontrak sampai waktu yang telah ditentukan hingga ada keputusan dari pemilik lahan untuk memanfaatkan lahan tersebut. Darwis (2008) menjelaskan bahwa sistem penguasaan lahan diklasifikasikan menjadi status hak milik sewa, sakap (bagi hasil) dan gadai. Status hak milik adalah lahan yang diku asai dan dimiliki oleh perorangan atau kelompok/organisasi, sementara menurut Pakpahan et.al (1992) status sewa, sakap (bagi hasil), dan gadai adalah bentuk-bentuk penguasaan lahan dimana terjadi pengalihan hak garap dari pemilik lahan kepada orang lain. Bentuk kelembagaan ini sudah menjadi bagian dari tatanan masyarakat pedesaan dimana keberadaan sifat dinamis antar ruang dan waktu. Jadi, lahan pertanian basah yang dialokasikan pada Peta Rencana Pola Ruang RTRW Kabupaten Bogor 2005-2025 adalah lahan dengan penguasaan atau kepemilikan kelompok tertentu. Kelompok ini merupakan perusahaan pengembang perumahan yang telah berdiri sebelum RTRW ditetapkan, maupun perusahaan yang telah merencanakan pembangunan perumahan namun terbentur dengan peruntukkan wilayah sebagai kawasan pertanian lahan basah yang sulit mendapatkan perijinan alih fungsi.

\section{Lokasi Strategis dan Kemudahan Aksesibilitas}

Beberapa kecamatan berbatasan dengan kota; Parung dan Ciseeng dengan Kota Depok, serta Ciomas dan Dramaga dengan Kota Bogor Barat. Karena berbatasan langsung dengan kota, wilayah tersebut mengalami perkembangan penduduk dengan kegiatan perekonomian non- pertanian yang cukup pesat sehingga kecenderungannya menjadi kawasan perkotaan. Menurut Desrainy (2010:6), peningkatan penduduk yang sangat cepat, mengakibatkan wilayah peri-urban Jabodetabekpunjur berkembang tidak terkendali, ditunjukkan dengan penggunaan lahan yang berkarakteristik perdesaan menjadi perkotaan. Ciomas mengalami peningkatan jumlah penduduk sebesar 36\% dari tahun 2005 ke tahun 2010 dengan kepadatan penduduk yang meningkat hampir $150 \%$, sedangkan Kecamatan Parung mengalami peningkatan jumlah penduduk sebesar $57 \%$ di selisih tahun yang sama (BPS Kabupaten Bogor, 2006 dan 2011).

Demikian juga Dramaga yang berbatasan dengan kota Bogor Barat. Kecamatan Dramaga cukup terkenal karena memiliki kampus pendidikan IPB Dramaga yang disekelilingnya berkembang hunian rumah tinggal/kos dan hunian perumahan seperti 
Komplek IPB Alam Sinarsari, Dramaga Cantik, Graha Aradea, Bumi Kartika Dramaga Raya, sarana pendidikan seperti sekolah dasar, sekolah menengah pertama dan sekolah menengah atas, sarana kesehatan seperti Rumah Sakit Medika Dramaga serta fasilitas lainnya (Hasil Observasi, 2013). Berdasarkan data, Dramaga mengalami peningkatan jumlah penduduk sebesar 39\% dari tahun 2005 ke tahun 2010 (BPS Kabupaten Bogor, 2006 dan 2011). Hal ini diperkuat dengan pernyataan dari beberapa narasumber mengenai faktor lokasi strategis dan kemudahan akses suatu wilayah yang dapat mempengaruhi perubahan penggunaan lahan, khususnya lahan pertanian menjadi lahan non-pertanian. Lokasinya menjadi strategis karena letaknya dekat dengan kota dengan kem udahan akses yaitu infrastruktur jalan raya (jalan arteri primer dan jalan tol) yang terintegrasi dengan wilayah pinggiran kota. Selain itu, kemudahan mencari lahan yang luas dengan harga yang relaif lebih murah dibandingkan dengan kota, sehingga banyak investor telah membangun bahkan akan rencana membangun perumahan.

\section{Ketidaktahuan/Ketidakpahaman terhadap Peraturan Daerah (RTRW/IMB)}

Mematuhi dan melaksanakan Peraturan Daerah adalah sebuah keharusan bagi seluruh pemangku kepentingan baik itu pemerintah, masyarakat maupun pihak swasta. Namun demikian, yang terjadi masyarakat maupun pemerintah level bawahpun kurang tahu/kurang paham atau bahkan tidak tahu/tidak paham mengenai Peraturan Daerah, seperti: Perda No. 19 Tahun 2008 tentang RTRW dan Perda No. 23 Tahun 2000 tentang IMB. Camat dan Sekcam cukup memahami arahan peruntukan RTRW Kabupaten mengenai wilayahnya, sedangkan untuk level Kasi hanya menguasai bidang yang sesuai dengan tugas, fungsi dan kewenangannya. Hampir seluruh aparat kecamatan memahami bahwa sebagian besar arahan tata ruang wilayahnya adalah kawasan lahan pertanian, demikian juga fungsi dari peraturan daerah mengenai IMB. Sedangkan amanat RTRW mengenai arahan peruntukan wilayahnya bagi aparat pemerintah desa maupun masyarakat tidak semua mengetahui dan memahami, hanya sebagian kecil saja. Hasil wawancara juga menjelaskan mengenai ketidaktahuan/ketidakpahaman atau kurang sadarnya masyarakat terhadap pengajuan IMB, meskipun upaya Pemerintah Kabupaten juga sudah dilakukan dengan pemasangan papan pemberitahuan terkait Perda IMB di beberapa jalan arteri sekunder, dan papan pemberitahuan mengenai Outlet Pelayanan Perijinan serta bagan mekanisme permohonan berbagai jenis perijinan yang dipasang di setiap kantor Kecamatan.

\section{Kurang Intensifnya Sosialisasi mengenai Peraturan Daerah RTRW/IMB}

Faktor ini merupakan cikal bakal mengapa para pemangku kep entingan seperti masyarakat, aparat pemerintah desa/kecamatan menjadi tidak paham/kurang paham atau bahkan tidak tahu/kurang tahu mengenai Perda yang telah ditetapkan. Pemerintah Kabupaten berwenang menyusun kebijakan/peraturan, sepatutnya juga melakukan sosialisasi kepada seluruh pemangku kepentingan. Menurut Madya (2008), salah satu faktor keluhan bagi pemohon IMB untuk rumah tinggal adalah informasi yang belum maksimal mengenai kebijakan IMB untuk rumah tinggal dari pihak Sub Dinas Tata Bangunan. Dalam pasal 12 dan 13 UU No.26 Tahun 2007, telah dijelaskan mengenai pembinaan penataan ruang, salah satunya adalah sosialisasi, memberikan pemahaman kepada aparat pemerintah, masyarakat dan pemangku kepentingan lainnya tentang substansi peraturan bidang penataan ruang. Demikian juga amanat pasal 97 Perda RTRW Kabupaten Bogor, bahwa pemerintah daerah menyebarluaskan rencana tata ruang melalui media pengumuman atau sosialisasi oleh pemerintah daerah.

Berdasarkan hasil wawancara dan analisis kualitatif, sosialisasi mengenai Perda RTRW tidak sering dilakukan oleh pemerintah kabupaten kepada aparat pemerintah 
kecamatan, sosialisasi dilakukan hanya jika ada usulan/permohonan perubahan tata ruang dari pemangku kepentingan lainnya, misalnya pihak swasta, dan ini dilakukan minimal setahun sekali saja. Karena memang berjenjang, aparat pemerintah kabupaten hanya mengadakan sosialisasi sampai tingkat aparat pemerintah kecamatan saja, dan oleh sebab itu banyak aparat pemerintah desa yang tidak mengetahui dan memahami mengenai peraturan daerah RTRW tersebut. Namun demikian, sosialisasi tidak berhenti di kecamatan saja, aparat pemerintah kecamatan juga melakukan sosialisasi / pemberitahuan kepada aparat pemerintah desa dan masyarakat. Sosialisasi bukannya tidak pernah dilakukan sama sekali oleh pemerintah kabupaten maupun aparat pemerintah kecamatan, namun permasalahannya adalah sosialisasi kurang intensif dilakukan kepada seluruh pemangku kepentingan, ada baiknya sosialisasi terkait RTRW menjadi agenda bagi pemerintah kabupaten maupun kecamatan sehingga arahan peruntukan wilayahnya dapat dijadikan acuan. Peraturan tidak hanya dibuat dan ditetapkan, melainkan dapat di implementasikan seca ra nyata. Selain itu, perlu juga dilakukan kerjasama antara pemerintah kabupaten dan pemerintah kecamatan untuk dapat memasang peta arahan RTRW di kantor-kantor kecamatan/desa. Karena hampir seluruh kantor kecamatan/desa yang menjadi sampel penelitian tidak ditemukan papan pemberitahuan berisi peta rencana tata ruang (Hasil Observasi, 2013).

Kurangnya Dukungan Pemerintah terhadap Keberadaan Inf rastruktur Saluran Irigasi yang berfungsi Mengaliri Lahan Pertanian Kabupaten Bogor memang mempunyai potensi pertanian lahan basah yang merupakan areal persawahan, pada wilayah ini umumnya tersedia jaringan irigasi baik teknis maupun pedesaan. Jaringan irigasi mempunyai peranan penting dalam mendukung produksi pertanian, sehingga kontinuitas aliran air irigasi dapat mengairi hamparan sawah. Dalam perda RTRW Kabupaten 2005-2025 juga telah ditegaskan, pengelolaan kawasan pertanian lahan basah melalui pengembangan sawah beririgasi teknis, dilakukan dengan memperioritaskan perubahan dari sawah tadah hujan menjadi sawah irigasi sejalan dengan perluasan jaringan irigasi dan pengembangan waduk/embung. Hal ini dimaksudkan untuk tetap mempertahankan luasan kawasan pertanian, disebutkan juga bahwa perubahan kawasan pertanian dapat dilakukan selama tersedia lahan pengganti. Arifin (2012) menegaskan bahwa kerusakan jaringan irigasi menjadi salah satu determinan paling penting dalam status lahan sawah produktif dan beririgasi teknis. Tingkat kerusakan jaringan irigasi bermacam-macam, mulai dari hanya sekedar sedimentasi atau penumpukan lumpur dalam jaringan, aliran tidak lancar, tidak berfungsinya jaringan pembagi air, sampai jebolnya saluran sehingga fungsi pengairan atau drainase tidak berjalan.

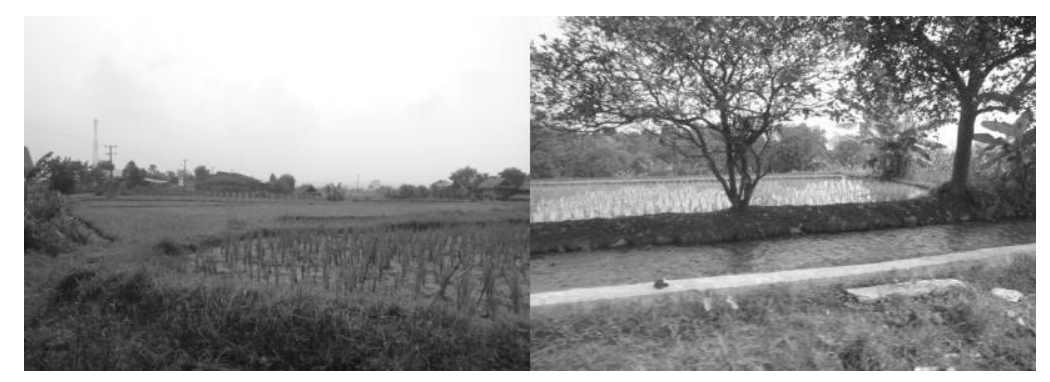

Gambar 7. Lahan Sawah dan Saluran Irigasi Desa Sukaharja, Kecamatan Ciomas

Perubahan penggunaan lahan pertanian basah menjadi lahan terbangun (perumahan/permukiman) memang diakibatkan oleh faktor saluran irigasi. Namun 
demikian, fenomena perubahan juga terjadi dari pertanian lahan basah menjadi lahan kering, sehingga padi sudah tidak bisa ditanami kembali dan diganti oleh tanaman palawija seperti singkong dan jagung atapun sayur-sayuran seperti: sayur, bayam, sawi dan sebagainya. Penelitian Budiman (2009), petani mengambil keputusan untuk merubah penggunaan lahan sawah miliknya menjadi kebun singkong dan kebun pepaya yang lebih menguntungkan dan memiliki siklus yang pendek, hal ini diakibatkan persediaan air untuk irigasi yang semakin menipis sehingga sulit untuk megairi sawah para petani.

Dibalik kejadian perubahan penggunaan lahan dan faktor pengaruhnya, terdapat wilayah yang mempertahankan sawahnya, selain memang karakteristik wilayah, produktivitasnya tinggi didukung dengan saluran irigasi (perawatan pemerintah Kabupaten), penyuluhan pertanian berupa informasi, dan bantuan subsidi seperti: pupuk, bibit dan alat mesin pertanian/traktor, misal: Desa Sukaharja di Kecamatan Ciomas, Desa Pasir Gaok dan Desa Bantarjaya di Ranca Bungur, serta Desa-desa di Kecamatan Ciampea, Cibungbulang dan Pamijahan.

\section{Pengendalian Pemanfaatan Ruang}

Pengendalian pemanfaatan ruang merupakan upaya mewujudkan tata tertib ruang yaitu bagaimana rencana tata ruang wilayah yang sudah dilegalkan menjadi Peraturan Daerah dan produk kesepakatan dapat diacu oleh seluruh para pelaku pembangunan. Rencana Tata Ruang tertuang dalam struktur ruang dan pola ruang disusun dalam bentuk program, kegiatan dan pembiayaannya. Pengendalian pemanfaatan ruang merupakan usaha untuk mengambil tindakan agar pemanfaatan ruang termasuk tata guna tanah, tata guna air, tata guna udara, dan tata guna sumber daya alam lainnya yang berada pada kawasan lindung, kawasan budidaya, kawasan perdesaan, dan kawasan perkotaan yang direncanakan dapat terwujud. Perwujudan pengendalian pemanfaatan ruang menggunakan instrumen pengendalian yaitu arahan peraturan zonasi, arahan perizinan, arahan pemberian insentif dan disinsnetif, arahan sanksi, dan arahan jasa lingkungan. Upaya pengendalian pemanfaatan ruang berakar dari 3 hal tersebut diatas yaitu rencana tata ruang, pemanfaatan ruang (tata guna tanah, tata guna air, tata guna udara, tata guna sumberdaya alam lainnya), dan instrumen pengendalian pemanfaatan ruang. RTRW yang berisi arahan pemanfaatan ruang yang sesuai dengan kondisi dan potensi wilayah dapat dilaksanakan apabila telah diketahui oleh para pemangku kepent ingan terkait. Sesuai hasil wawancara dan analisis kualitatif dengan narasumber yang merupakan aparat kecamatan, upaya pengendalian pemanfaatan ruang (penertiban dan pengawasan) telah dilakukan yaitu bekerjasama dengan aparat Kabupaten di dalam Tim 9 melalui penegakan hukum dan keamanan ketertiban terkait implementasi dari RTRW Kabupaten Bogor dan IMB.

Dalam upaya pengendalian pemanfaatan ruang melalui pengawasan dan penertiban penataan ruang terkait dengan fenomena perubahan penggunaan lahan pertanian basah (areal persawahan) menjadi lahan terbangun (permukiman/perumahan), ada beberapa hal yang perlu dipahami dan diketahui mengenai pentingnya sawah dalam hal pelestarian sumber daya alam dan lingkungan. Selain pentingnya lokasi penelitian yang berada di bagian hulu daerah aliran sungai Cisadane, wilayah dengan karakteristik alami seperti: curah hujan tinggi, vegetasi lebat, topografi tinggi, aliran sungai maupun anak sungai Cisadane penting bagi kehidupan dan keberlanjutan ekosistem lingkungan, serta wilayahnya yang merupakan kawasan konservasi air dan tanah, yang juga sekaligus menjadi kawasan yang rawan erosi, tanah longsor maupun banji $r$. Ditambah lagi dengan posisinya yang merupakan wilayah pinggiran kota yaitu wilayah yang rentan terhadap pelebaran perkembangan perkonomian kota, sehingga menyebabkan pergeseran penduduk dan aktivitasnya. Pelebaran ini menyebabkan peningkatan kebutuhan lahan untuk pengembangan kawasan permukiman dan sarana prasarana lainnya, yang pada akhirnya 


\section{Evaluasi Perubahan Penggunaan Lahan Kecamatan di Daerah Aliran Sungai Cisadane Kabupaten Bogor}

mengorbankan keberadaan lahan pertanian basah yang masih produktif. Iman dan Pribadi (1999), salah satu faktor pengaruh perubahan penggunaan lahan adalah pembangunan dan tata ruang kota yang masuk ke dalam wilayah geografis DAS, lahan-lahan pertanian beralihfungsi menjadi penggunaan lahan non-pertanian bersifat permanen, sehingga luas lahan pertanian akan berkurang.

\section{Temuan Hasil Penelitian}

1. Alokasi rencana pola ruang tahun 2005-2025 di wilayah studi adalah kawasan lindung 25,43\% merupakan kawasan hutan konservasi dan kawasan budidaya 74,57\%; didominasi oleh kawasan pertanian lahan basah 22,78\%. Eksisting penggunaan lahan tahun 2010 di wilayah studi didominasi oleh pertanian dan tegalan 53,6\%; semak dan hutan 28,8\%, dan permukiman dan perumahan 15,55\%.

2. Prosentase kesesuaian antara peta rencana pola ruang tahun 2005-2025 dan peta penggunaan lahan tahun 2010 yaitu sesuai $63,39 \%$, kurang sesuai $26,38 \%$, dan tidak sesuai 10,23\%. Dari prosentase 10,23\%; terdapat 3 jenis perubahan penggunaan lahan yaitu perubahan tutupan lahan 47,65\%; perubahan lahan tak terbangun menjadi lahan terbangun 44,33\%; dan perubahan peruntukan lahan 8,02\%. Dari total perubahan lahan tak terbangun menjadi lahan terbangun; $65,75 \%$ penggunaan lahan perumahan/permukiman, perindustrian dan fasilitas umum lainnya berada di atas ketetapan kawasan pertanian lahan basah.

3. Perubahan penggunaan lahan pertanian menjadi lahan perumahan/permukiman memang benar terjadi dalam kurun waktu sebelum maupun sesudah penetapan kawasan pertanian lahan basah. Perubahan penggunaan lahan ini menunjukkan bahwa RTRW belum menjadi acuan dalam pelaksanaan pembangunan, bahwa perencanaan ruang belum diimplementasikan secara penuh oleh para pelaku pembangunan ke dalam sebuah pemanfaatan ruang.

4. Faktor-faktor pengaruh perubahan penggunaan lahan tersebut, yaitu:

a. faktor sosial ekonomi (internal), antara lain: kebutuhan rumah tinggal dan kepemilikan lahan, lokasi strategis dan kemudahan aksesibilitas, dan ketidaktahuan/ ketidakpahaman terhadap Peraturan Daerah RTRW/IMB;

b. faktor kelembagaan (eksternal), antara lain: kurang intensifnya sosialisasi Perda RTRW/IMB, dan kurangnya dukungan pemerintah terhadap keberadaan saluran irigasi yang berfungsi mengaliri lahan pertanian sehingga menyebabkan penurunan produktivitas dan alih fungsi menjadi pertanian lahan kering ataupun permukiman.

5. Beberapa faktor yang perlu diperhatikan terkait implementasi Rencana Pola Ruang RTRW Kabupaten Bogor, khususnya alokasi kawasan pertanian lahan basah/lahan kering, yaitu:

a. Kepemilikan lahan, bahwa lahan pertanian basah maupun lahan pertanian kering berada dalam penguasaan atau kepemilikan perseorangan/kelompok;

b. Keberadaan infrastruktur saluran irigasi, bahwa saluran irigasi yang berfungsi mengaliri lahan kurang/terhambat aliran airnya, sehingga lahan pertanian basah beralihfungsi menjadi lahan pertanian kering (ditanami palawija dan sayursayuran yang lebih menguntungkan) maupun lahan terbangun (bangunan rumah tinggal).

6. Aparat Kecamatan dan aparat Kabupaten berupaya mengendalikan pemanfaatan ruang dalam bentuk Tim-9 melalui pengawasan kontrol pemanfaatan ruang dan penertiban bangunan- bangunan sesuai RTRW/IMB yang berlaku. 


\section{Kesimpulan}

Proses suburbanisasi yang dijelaskan Rustiadi et.al (2003), disebabkan karena meluasnya perkembangan kawasan permukiman di wilayah pinggiran kota dan proses konversi lahan yang merupakan lahan-lahan produktif. Hal ini terjadi di wilayah daerah aliran sungai Cisadane, bahwa aktivitas perkotaan berdampak pada alih fungsi lahan pertanian menjadi permukiman (transformasi penggunaan lahan). Pola Ruang dalam RTRW Kabupaten Bogor telah menetapkan ketentuan dominasi kawasan pertanian lahan basah didasarkan potensi dan karakteristik wilayah, namun yang terjadi adalah penggunaan lahan pertanian beralihfungsi menjadi lahan perumahan/permukiman. Bahkan perubahannya pun terjadi sebelum ditetapkannya menjadi kawasan pertanian lahan basah.

Perubahan penggunaan lahan secara langsung berkaitan dengan ketahanan pangan, manusia, urbanisasi, hilangnya keanekaragaman hayati dan lain sebagainya (Mendoza et.al, 2011), namun faktor sosial ekonomi memicu para pengembang mengalihfungsikan lahan pertanian menjadi kawasan perumahan dengan nilai tambah (aksesibilitas), tak terkecuali warga dengan hak kepemilikannya. Warga bebas merubah lahan sawah menjadi lahan kering (lebih menguntungkan) atau dijadikan rumah tinggal. Isa (2008) menjelaskan bahwa implementasi penataan ruang merupakan penerapan kepentingan publik terhadap tanah yang dilekati hak, sehingga diperlukan strategi penyelenggaraan pengaturan penguasaan, pemilikan, penggunaan dan pemanfaatan tanah. Selain itu, faktor kelembagaan, kurangnya komitmen pemerintah menjalankan tugasnya dalam pelayanan terhadap keberadaan saluran irigasi dan keberlanjutan aliran irigasi yang berfungsi sebagai sarana prasarana utama. Sugandhy (1999:96-97) menuliskan bahwa lahan-lahan pertanian mutlak dilestarikan fungsinya dan dibatasi konversinya dari bentuk penggunaan lahan nonpertanian, di dalamnya terdapat aset saluran irigasi teknis dan sebagai upaya swasembada dan ketahanan pangan. Namun alih fungsipun tetap terjadi, Arifin (2012) menuliskan bahwa sawah yang semula beririgasi teknis, akhirnya berubah menjadi sawah tadah hujan, bahkan secara perlahan berubah menjadi lahan kering, tidak subur, dan tidak produktif.

Penerapan pengendalian pemanfaatan ruang telah dilakukan oleh aparat kecamatan bekerjasama dengan aparat kabupaten melalui kegiatan pengawasan dan penertiban sesuai dengan ketentuan RTRW/IMB yang berlaku, namun hal ini belum diimbangi oleh sosialisasi kepada masyarakat, masih banyak masyarakat maupun aparat pelaksana belum mengetahui dan memahami peraturan tersebut sehingga kecenderungan terjadinya alih fungsi lahan cukup tinggi.

\section{Daftar Pustaka}

Alberto et. al. 2010. "Model Perubahan Penggunaan Lahan dan Pendugaan Cadangan Karbon di Daerah Aliran Sungai Cisadane, Jawa Barat”. Jurnal Agromet 24 (2):18-26. IPB.

Arifin, Bustanul. 2012. “Bahaya Konversi Lahan Sawah”. Kolom MetroTV News, 22 Mei 2012.

Bappeda Kabupaten Bogor, 2008. Mateks RTRW Kabupaten Bogor Tahun 2005-2025.

Bintarto. 1984. Urbanisasi dan Permasalahannya. Jakarta : PT. Ghalia Indonesia.

Bryon dan Leslie. 2008. Spatial Methodologies for Integrating Social and Biophysical Data at a Regional of Catchment Scale. Land Use Change: Science, Policy and Management. London.

Budiman, Yohan. 2009. Konversi Lahan Pertanian sebagai Strategi Adaptasi Petani (Kasus di RW 02 Desa Gunung Picung, Kecamatan Pamijahan, Kabupaten Bogor). IPB.

BPS Kabupaten Bogor. 2011. Kabupaten Bogor Dalam Angka. Bogor. 2006. Kabupaten Bogor Dalam Angka. Bogor.

Creswell, J.W dan Clark, P.V. 2007. Designing and Conducting Mixed Methods Research. London: Sage. 


\section{Evaluasi Perubahan Penggunaan Lahan Kecamatan di Daerah Aliran Sungai Cisadane Kabupaten Bogor}

Darwis, Valerina 2008. Keragaan Penguasaan Lahan Sebagai Faktor Utama Penentu Pendapatan Petani. Semnas Dinamika Pembangunan Pertanian dan Perdesaan, Bogor 19 November 2008. Desrainy. 2010. Karakteristik Wilayah Peri Urban pada Metropolitan Jabodetabekpunjur. Working Paper. Regional and Rural Planning Resarch Group. ITB.

Djakapermana, Ruchyat Deni. 2008. RTR Kawasan Jabodetabekpunjur: Upaya Menyeimbangkan Pertumbuhan Ekonomi Dengan Kelestarian Lingkungan Hidup. Butaru Juli-Agustus 2008.

Emilda, Ade. 2010. Dampak Perubahan Penggunaan Lahan Terhadap Respon Hidrologi DAS Cisadane Hulu. Progam Pascasarjana. IPB.

Iman dan Pribadi. 1999. "Analisis Spasial Konversi Lahan di Daerah Aliran Sungai (Kawasan Hulu DAS Cimanuk)". Seminar Sehari "Penerapan Sistem Informasi Geografi dan Radiotracking untuk Pengelolaan Keanekaragaman Hayati. Bogor 26 Oktober 1999.

Isa, Iwan Taruna. 2008. Penataan Ruang dalam Perspektif Pertanahan. Buletin Tata Ruang, Edisi Maret- April 2008.

Koomen dan Stilwell. 2007. Modelling Land Use Change: Theories and Methods. Buku Modelling Land Use Change. Belanda: Springer.

Madya, Faizal. 2008. "Implementasi Kebijakan Izin Mendirikan Bangunan di Kabupaten Bogor." Jurnal Organisasi dan Manajemen, Vol 4 (2):130-138.

Mendoza, et.al. 2011. "Analysing Land Cover And Land Use Change Processes At Watershed Level: A Multitemporal Study In The Lake Cuitzeo Watershed Mexico (1975 -2003)”. Applied Geography, Vol $31: 237-250$

Peraturan Daerah Kabupaten Bogor No. 23 Tahun 2000. Ijin Mendirikan Bangunan.

Peraturan Daerah Kabupaten Bogor No. 19 Tahun 2008. RTRW Kabupaten Bogor Tahun 2005-2025.

Puspaningsih. 1999. "Studi Perencanaan Pengelolaan Lahan di Sub-DAS Cisadane Hulu Kabupaten Bogor. Jurnal Manajemen Hutan, Vol 5 (2): 45-53.

Rustiadi, et.al. 2003. "Analisis Kecenderungan dan Dampak Proses Suburbanisasi Wilayah Jabodetabek: Suatu Upaya Pengembangan Model Pembangunan Wilayah Metropolitan”.

Strauss, Anselm dan Corbin, Juliet. 1990. Basics of Qualitative Research: Grounde Theory Procedures and Techniques. Sage Publications: California.

Suripin. 2003. "Konservasi Daerah Aliran Sungai Secara Holistik." Makalah disampaikan pada Seminar Pengelolaan Sungai Yang Berkelanjutan, Semarang 5 Agustus 2003.

Yunus, Hadi S. 2008. Konsep Pendekatan Geografi: Memaknai Hakekat Keilmuannya. Sarasehan Forum Pimpinan Pendidikan Tinggi Geografi Indonesia, Yogyakarta 18-19 Januari 2008.

Zamrin. 2007. Evaluasi Kualitas Air Sungai Cisadane di Kabupaten Bogor Periode 1999-2003. Semnas Dinamika Pembangunan Pertanian dan Perdesaan: Bogor, 19 November 2008. 